\title{
SYNCHRONISING TENDER DRAWINGS AND DOCUMENTS AS AN AID FOR DISCREPANCIES
}

\author{
Iznny Ismail1,a, Azman Zainonabidin ${ }^{2}$, Teh Zahariah Nassaruddin ${ }^{3}$ and Rodzyah Mohd Yunus ${ }^{4}$ \\ 1, 2 Department of Architecture, Faculty of Architecture, Planning \& Surveying, \\ Universiti Teknologi MARA Campus Seri Iskandar, 32610 Perak, Malaysia \\ ${ }^{3}$ Department of Quantity Surveying, Faculty of Architecture, Planning \& Surveying, \\ Universiti Teknologi MARA Campus Seri Iskandar, 32610 Perak, Malaysia \\ ${ }^{4}$ Department of Architecture, Faculty of Architecture, Planning \& Surveying, \\ Universiti Teknologi MARA Campus Shah Alam, 54000 Selangor, Malaysia
}

\begin{abstract}
This paper recommends an aid to control discrepancies between drawings and documents in a project. The synchronisation may assist to better project's preparation and documentations. The causes of discrepancies that found out during the contract stage may lead to ineffectiveness of construction cost. The controlling process initiated from the tendering stage as to minimize the causal by any of the consultants which some items may left behind or possibly not describe fully without the thorough affiliation of coordination. The method to reduce discrepancies between drawings and documents is identified through Case Study based on 'hands on' project. The case study is focused on the preparation of architectural detailing. Therefore, the relationship of 2-Dimensional (2-D) Tender Drawings and bills of quantities is compared with the Elements of Building Works by Malaysian Standard Method of Measurement of Building Works Second Edition (SMM). The relationship study will simplify and supersede any unnecessary detailing. Thus, the application of the synchronisation method will result effectiveness of documentation during the contract stage by reducing discrepancies.
\end{abstract}

\section{Introduction}

Discrepancies of Tender Drawings and Documents are identified during contract stage. The process involved contractor's findings when he plans the carrying out of constructional works. According to PAM Contract 2006 [1], during the planning and subsequent execution of the works, the contractor needs to notify the architect in writing when they find any discrepancies between documents. Hence, with the notification architect shall enable to issue written instructions in sufficient time before any commencement of works regarding discrepancies. It nevertheless encourages contractor not to request further instruction at the very last minute to avoid delays. To the same degree, PWD Form 203A [2], stated that the contractor shall immediately notify the Superintending Officer (S.O.) a written notice for any discrepancy and divergence as for the S.O. to issue instructions.

Discrepancies happen among consultants' documentations [3]. Thus, discrepancies involved neither architectural and engineering drawings, nor engineering and engineering drawings, nor architectural drawings and bills of quantities, nor engineering drawings and bills of quantities. In accordance with the documentation, client's requirements are complex nowadays [4]. In supporting to the complexity, a great deal of coordination is required to avoid delay, especially for public projects [5].

Many researchers have studied on the effects and causes of delays and cost overrun and all suggested early detection and planning. Sambasivan and Soon [6] recommended that practitioners to better understand the dynamics of project management and make an effort to reduce delays, whereas and academicians can conduct similar studies to identify causes and effects of delays. At the preliminary stage of the project, it is essential that effective decisions on design specifications, project financing, contractual systems, and methods of construction are all taken at the right time [7]. Odeh and Battaineh [8] listed that one of the causes of delay is contract factors include changed orders and mistakes with discrepancies in contract documents. Actions are taken to control the causes of delay and cost overruns right away from the planning to the implementation and management stages [5]. Analysis has been made by Cheng [9] cost impact factor and contract dispute highlighted on construction drawings are unclear with ambiguous specifications. The study made by [4] ranked that one of the factor influencing cost variance during construction is incomplete design drawings and specification. Thus, understanding the relationship between drawings and documents is crucial in achieving synchronization. This paper is organized as follows. Section 2 deals on explanation on drawings and

\footnotetext{
${ }^{1}$ Iznny Ismail: iznny813@perak.uitm.edu.my
} 
documents. Section 3 explains on the methodology and conceptual framework of the research. Section 4 discusses the analysis of findings. Section 5 presents the conclusion and recommendation.

\section{Literature review}

\subsection{Understanding the relationship of drawings and specifications}

Drawings and specifications always been treated as different means of resources. Rosen and Regener [10] recommended the relationship should be complementary with no duplication or conflict between drawings and documents. Arditi and Gunaydin [11] described that it is critical that drawings and specifications be clear, concise, and uniform; the project must be constructible from those retained to build the project; design professionals must be familiar with construction materials and techniques that constructors will be using in the project. Contract documents contained specifications, as written instructions, are frequently judged by the courts as having greater importance than drawings when these documents are in conflict, with judgments based usually on what is contained in the specifications. This means that specifications should be carefully prepared by knowledgeable people [10] . On the other hand, Connell and Flegal [12] identified that drawings depict the work graphically and the specifications provide a written description, while addenda and modifications are official changes to both. Quality project built by a contractor is directly related to the quality of plans and specification [13]. The authors suggest that a relationship of drawings and specifications are uniform without duplication of information as for the purpose of contractors fulfilling their obligations. Thus, if the resources are well prepared, discrepancies can be avoided and lessen wastage of time and cost.

\subsubsection{Information and graphic for 2-dimensional (2-D) drawings}

The drawings illustrate a series of information that describes in graphics. Drawings are the only documents given to the constructor that show the design concept, size and scope of the job [11]. Another author described that drawings present series of pictures of a project to be constructed that indicate size, form, location and arrangement of various elements [10].

\subsubsection{Measurement for specifications}

Specifications complement the drawings that provided for each project. Rosen and Regener [10] distinguished that the purpose of specifications should describe the type and quality of every work; quality of workmanship; requirements for fabrication, erection, application, installation and finishing; applicable regulatory requirements; overall and components dimension; specific descriptions and procedures for allowance of unit prices ;specific descriptions and procedures for product options; and specific requirements for administration of contract for construction. According to PAM Contract 2006 [1], clause 12., measurement of building works relating to the quality and quantity of the work included in the Contract Sum shall be deemed to be those which are set out in the Contract Bills and unless otherwise expressly stated, shall be prepared in accordance with the Principles of the Standard Method of Measurement of Building Works (SMM) sanctioned by the Institution of Surveyors Malaysia (ISM) and currently in force. However Harbans and Kandan [14] recognized the uncertainty of measurement the contractual provisions, methods for measuring the varied work applying SMM for building works and CESMM for civil engineering works, but to the contrary mechanical and electrical works there are no accepted norms in the measurement process. Despite of that, Connell and Flegal [12] mentioned the use of standards is extremely important.

Jaafar, Lim, and Yahaya [15] explained that elementary estimating for building works, during the preliminary design stage, project estimation is prepared and estimation involves measuring and pricing. The author clarified that measuring is the process of abstracting Standard Method of Measurement (SMM) and the quantity of each building element will be compiled as Bills of Quantity. On the other hand, pricing is the process of calculating the cost of each building element stated in the Bills of Quantity. The actual building estimation is based on detailed drawings such as layout plans, elevations, sections and supported by a specific list of building elements.

Table 1 . Elements of building works by

Malaysian standard method of measurement of building works second edition (SMM)

\begin{tabular}{|l|l|}
\hline Building Elements & Role by Consultant \\
\hline Preliminaries & All Consultants \\
\hline Demolitions & All Consultants \\
\hline Excavation and Earthwork & Civil Engineer \\
\hline Piling and Diaphragm Walling & Structural Engineer \\
\hline Concrete Work & Structural Engineer \\
\hline Brickwork and Blockwork & Architect \\
\hline Underpinning & Civil Engineer \\
\hline Masonry & Architect \\
\hline Waterproofing and Asphalt work & Architect \\
\hline Roofing & Architect and \\
& Structural Engineer \\
\hline Woodwork & Architect \\
\hline Structural Steelwork & Structural Engineer \\
\hline Metalwork & Architect \\
\hline Plumbing and Mechanical Engineering & Architect and \\
Installations & Mechanical \\
& Engineer \\
\hline Electrical Installations & Electrical Engineer \\
\hline Floor, Wall and Ceiling Finishings & Architect \\
\hline Glazing & Architect \\
\hline Painting and decorating & Architect \\
\hline Drainage & Civil Engineer \\
\hline Fencing, Turfing and Planting & Architect \\
\hline
\end{tabular}




\subsection{Coordination of 2-dimensional (2-D) drawings and specification}

Coordination plays the role of the team player in a project. Rosen and Regener [10] emphasized that to improve coordination between drawings and specifications, standardization of information should be appearing in them. Coordination is one of the factors to minimize discrepancies. The list comprises of:

(1) Closer consultant coordination is required at design stage;

(2) Closer consultant coordination and utilization of an experienced consultant to produce a concluding design, working drawings, and contract drawings at the tender stage;

(3) Checking and reviewing the contract documents;

(4) Develop a clear scope of work for the parties that involved on the project;

(5) Integrated project scheduling and management techniques;

The coordination factors numbered (1)-(4) suggested on closer coordination, thorough checking, and develop clear technical detailing that integrated with conclusive design. Whereas factor numbered (5) is a suggestion during the construction stage. Coordination before tendering stage is important due to making sure the documents and drawings are described conclusively. Simply to avoid some items may leave out or possibly not describe fully. The coordination process will get more tedious, according to the complexity of the project. It is a careful process of making sure the documentation final.

\section{Methodology and conceptual framework}

This research involved qualitative mode of research. Love, Lopez, Edwards, and Goh [16] recommended that a case study approach based upon analytic induction is used to further examine the underlying dynamics that may contribute to design error production. Furthermore, the research is guided by De Massis and Kotlar [17] suggested for choosing the case study design, identify the unit analysis (case), selecting the cases (sampling), collecting information, and analysing information. Implementing the guideline, the case study design is a descriptive case study that used to convince a phenomenon that is relevant, as referring to "Synchronise drawings and documents can be an aid for discrepancies". The purpose is to understand project in depth regarding ways or method in minimizing discrepancies. The unit analysis is focusing on a project within the firm with an experienced individual. It involved 'hands on' case studies for research approach that involved five (5) years of experienced in handling multiple projects. Sampling of the case study is by a single case for aiming straightforward information related to architectural detailing and specifications. The case studies are based on projects in Perak, Malaysia that involve the building type of an office building. The information is gathered from tender drawings and documents which consist of research techniques are from observations and appropriate written documents. The information is analysed through two steps, firstly by comparison and to be followed by synchronizing data.

Chart 1. The framework of methodology

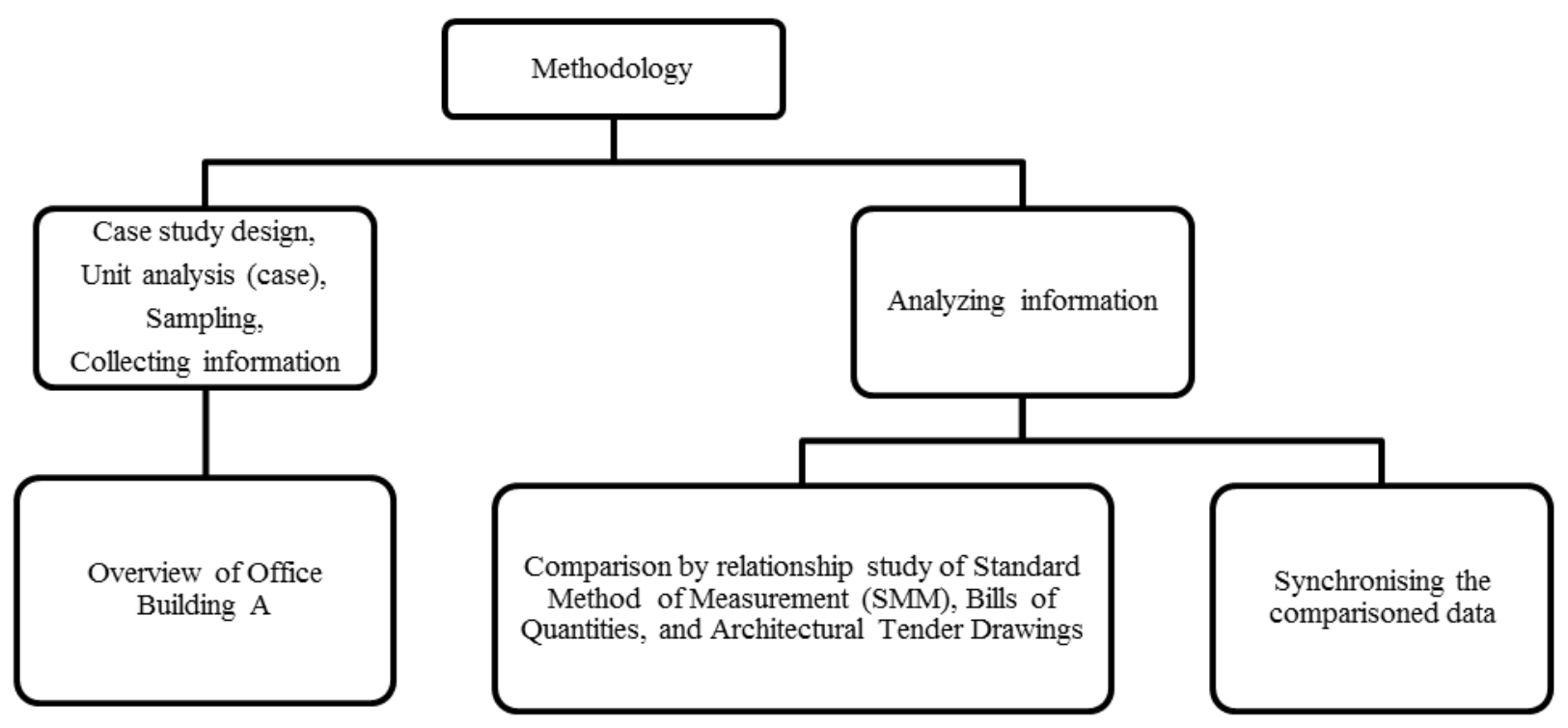


Figure 1. Perspective of Office Building A

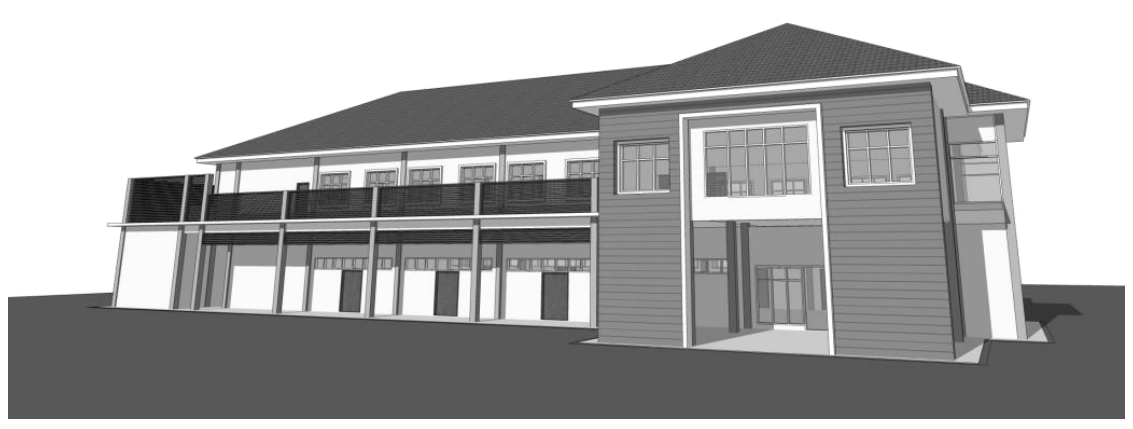

\section{Findings and discussion}

\subsection{Overview of Office Building A}

A single case study is identified based on a project in Perak, Malaysia. The case study building type is a government office building that approximately cost RM 2,500,000 (Ringgit Malaysia Two Million and Five Hundred Thousand. The project is managed by a project architect with five (5) years of project handling experience. The observations are dominantly from the architectural side of the input. The client of the project follows the project phases by following the submission plan approval timeline and just then proceed to the next stage after gain all approvals. The time allocation is carefully planned and follows as this is the first implementation by the client to bind the work programme part of the Memorandum of Agreement (MOA) between the client and each of the consultants. This means that the client can claim damages towards some late progress of the consultants because the work programme has been legalized. This policy already implemented by the government in minimizing delays in the consultant's scope of work. All progress between client and consultants has been clarified with clear brief, close coordination, detailed forecast, clear communication, careful budgetary consideration, and conclusive documents and drawings for quality assurance.

\subsection{Relationship between Standard Method of Measurement (SMM) with bills of quantities and architectural tender drawings.}

The comparison is to identify the relationship between the building element of Standard Method of Measurement (SMM) with bills of quantities (gathered information from quantity surveyor) and architectural tender drawing (gathered information from architect).The bills of quantities provided is prepared in accordance of SMM. From this comparison, some of the elements in the bills repeated as to follow the elements of SMM. For example the staircase element in bills of quantities has been repeated under building element concrete works, metal works, and floor, wall, and ceiling finishings. The assortments of drawings and documents are identified through the comparison with SMM.
4.3 Relationship between bills of quantities with Standard Method of Measurement (SMM) and architectural tender drawings.

In accordance with the comparison of table 2, another related study is taken. The comparison is done on the elements of building works of bills of quantities between architectural tender drawings and building elements of Standard Method of Measurement (SMM). This comparison simplifies the elements in the bills of quantities. Besides, multiple building elements are grouped related to one element in the bills of quantities. For example relationship between the staircase element in the bills of quantities to be compared with Detail Staircase comprises building elements of concrete work, metalwork, and floor, wall and ceiling finishings. Some of the architectural tender drawings are repeated under different building works element in the bills of quantities. Hence, the relationship between architectural tender drawings and SMM is cluttered, but to be compared with bills of quantities, the architectural tender drawings are in order. However, the relationship has to be simplified further.

\subsection{Corresponding between bills of quantities with architectural tender drawings}

In relation to the table 3 , the bills of quantities, elements are simplified by omitting the elements to be measured under different bills and not required in the design. However, there is still repeating Architectural Tender drawing in accordance to the element in the bills of quantities. For example the element between Internal Doors and Windows and External Doors and Windows, the architectural drawings of Detail Door, Detail Window, and Detail ironmongery are repeated. This synchronization is not conclusive as it will bring difficulty during managing architectural drawings.

\subsection{Corresponding between architectural tender drawings with bills of quantities}

In relation to table 4 , tabulation is made in synchronizing between the architectural drawings and bills of quantities. Each of the elements already been clarified as to improve the outcome of the recommended model of synchronizing drawings and documents. Architectural tender drawings are identified relating to the elements in the bills of quantities as for easier coordination purposes. 
Table 2. Comparison between building elements of SMM with bills of quantities and architectural tender drawings for office building A

\begin{tabular}{|c|c|c|}
\hline Building Element-SMM & $\begin{array}{c}\text { Bills of Quantities } \\
\end{array}$ & Architectural Tender Drawings \\
\hline A Preliminaries & *To be measured under different bill & Preliminaries Item \\
\hline C Demolition & $*$ Not required in the design & $*$ No design provided \\
\hline D Excavation and Earthwork & *To be measured under different bill & * Not under scope of work \\
\hline $\begin{array}{l}\text { E Piling and Diaphragm } \\
\text { Walling }\end{array}$ & Work Below Lowest Floor Finish & * Not under scope of work \\
\hline \multirow[t]{7}{*}{ F Concrete Work } & Frame & $*$ Not under scope of work \\
\hline & Staircase & Detail Staircase (Concrete works) \\
\hline & Staircase & $\begin{array}{l}\text { Detail Apron, Ramps, Steps And } \\
\text { Perimeter Drain (Steps) }\end{array}$ \\
\hline & $\begin{array}{l}\text { Apron Ramps and Perimeter Drain } \\
\text { (Ramp) }\end{array}$ & $\begin{array}{l}\text { Detail Apron, Ramps, Steps And } \\
\text { Perimeter Drain (Ramp) }\end{array}$ \\
\hline & Upper Floor Construction & $*$ Not under scope of work \\
\hline & Builders Work in Connection & Detail Ablution \\
\hline & Roof (flat roof) & Scupper Drain Detail (flat roof) \\
\hline \multirow[t]{3}{*}{ G Brickwork and Blockwork } & External Wall & Detail External \& Internal Wall \\
\hline & Internal Wall and Partition & Detail External \& Internal Wall \\
\hline & Builders Work in Connection & Detail Sanitary Fitting (Ablution) \\
\hline H Underpinning & $*$ Not required in the design & $*$ Not under scope of work \\
\hline J Masonry & *Not required in the design & * No design provided \\
\hline \multirow{2}{*}{$\begin{array}{l}\text { K Waterproofing and Asphalt } \\
\text { Work }\end{array}$} & Builders Work in Connection & Detail Ablution \\
\hline & Roof (flat roof) & Scupper Drain Detail (waterproofing) \\
\hline \multirow[t]{2}{*}{ L Roofing } & Roof & Detail Roof \\
\hline & Roof (flat roof) & Scupper Drain Detail (flat roof) \\
\hline \multirow[t]{6}{*}{ M Woodwork } & External Doors and Windows & Detail Door \\
\hline & External Doors and Windows & Detail Window \\
\hline & External Doors and Windows & Detail Ironmongery \\
\hline & Internal Doors and Windows & Detail Door \\
\hline & Internal Doors and Windows & Detail Window \\
\hline & Internal Doors and Windows & Detail Ironmongery \\
\hline N Structural Steelwork & *Not required in the design & * Not under scope of work \\
\hline \multirow[t]{6}{*}{ P Metalwork } & External Doors and Windows & Detail Door \\
\hline & External Doors and Windows & Detail Window \\
\hline & Internal Doors and Windows & Detail Door \\
\hline & Internal Doors and Windows & Detail Window \\
\hline & Staircase & Detail Staircase (Railing) \\
\hline & External Wall & Detail Louvres \\
\hline \multirow{5}{*}{$\begin{array}{l}\text { Q Plumbing and Mechanical } \\
\text { Engineering Installations }\end{array}$} & Sanitary Fittings & Detail Sanitary Fitting \\
\hline & Sanitary Fittings & Sanitary Fitting Schedule \\
\hline & Builders Work in Connection & Detail Ablution \\
\hline & Cold Water and Sanitary Plumbing & * Not under scope of work \\
\hline & $\begin{array}{l}\text { *To be measured under different bill } \\
\text { (Mechanical) }\end{array}$ & * Not under scope of work \\
\hline R Electrical Installations & $\begin{array}{l}\text { *To be measured under different bill } \\
\text { (Electrical) }\end{array}$ & * Not under scope of work \\
\hline \multirow{7}{*}{$\begin{array}{l}\text { S Floor, Wall and Ceiling } \\
\text { Finishings }\end{array}$} & Internal Floor Finishes & Detail Internal Floor Finishes \\
\hline & Internal Floor Finishes & Detail Skirting Finishes \\
\hline & Internal Wall FInishes & Detail Wall Finishes \\
\hline & Internal Ceiling Finishes & Detail Internal Ceiling Finishes \\
\hline & External Finishes & Detail Wall Finishes \\
\hline & External Finishes & Detail Feature Wall \\
\hline & Staircase & Detail Staircase (Finishes) \\
\hline T Glazing & *Not required in the design & $*$ No design provided \\
\hline U Painting and decorating & *To be measured with finishes & $*$ Details provided under finishes \\
\hline V Drainage & $\begin{array}{l}\text { Apron Ramps and Perimeter Drain } \\
\text { (Drain) }\end{array}$ & $\begin{array}{l}\text { Detail Apron, Ramps, Steps And } \\
\text { Perimeter Drain (Drain) }\end{array}$ \\
\hline W Fencing, Turfing and Planting & *Not required in the design & *No design provided \\
\hline *Others & Flag Pole (Provisional Item) & Detail Flag Pole \\
\hline
\end{tabular}

${ }^{1}$ Iznny Ismail: iznny813@perak.uitm.edu.my 
Table 3. Comparison of elements of building works between bills of quantities of building works, architectural tender drawings and SMM for office building A

\begin{tabular}{|c|c|c|}
\hline Bills of Quantities & Architectural Tender Drawings & Building Element-SMM \\
\hline $\begin{array}{l}\text { *To be measured under different } \\
\text { bill }\end{array}$ & Preliminaries Item & A Preliminaries \\
\hline Work Below Lowest Floor Finish & $*$ Not under scope of work & E Piling and Diaphragm Walling \\
\hline \multirow[t]{2}{*}{$\begin{array}{l}\text { Apron Ramps and Perimeter } \\
\text { Drain }\end{array}$} & $\begin{array}{l}\text { Detail Apron, Ramps, Steps And } \\
\text { Perimeter Drain (Apron \& Ramp) }\end{array}$ & F Concrete Work \\
\hline & $\begin{array}{l}\text { Detail Apron, Ramps, Steps } \\
\text { Perimeter Drain (Drain) }\end{array}$ & V Drainage \\
\hline Frame & $*$ Not under scope of work & F Concrete Work \\
\hline Upper Floor & $*$ Not under scope of work & F Concrete Work \\
\hline \multirow[t]{5}{*}{ Staircase } & Detail Staircase (Concrete works) & F Concrete Work \\
\hline & Detail Staircase (Railing) & P Metalwork \\
\hline & Detail Staircase (Finishes) & S Floor, Wall and Ceiling Finishings \\
\hline & \multirow{2}{*}{$\begin{array}{l}\text { Detail Apron, Ramps, Steps And } \\
\text { Perimeter Drain (Steps) }\end{array}$} & F Concrete Work \\
\hline & & S Floor, Wall and Ceiling Finishings \\
\hline Roof & Detail Roof & L Roofing \\
\hline \multirow{3}{*}{ Roof (flat roof) } & \multirow{3}{*}{ Scupper Drain Detail (flat roof) } & F Concrete Work \\
\hline & & L Roofing \\
\hline & & K Waterproofing and Asphalt work \\
\hline \multirow[t]{2}{*}{ External Wall } & Detail External \& Internal Wall & G Brickwork and Blockwork \\
\hline & Detail Louvres & P Metalwork \\
\hline Internal Wall and Partition & Detail External \& Internal Wall & G Brickwork and Blockwork \\
\hline \multirow{5}{*}{ External Doors and Windows } & \multirow[t]{2}{*}{ Detail Door } & M Woodwork \\
\hline & & P Metalwork \\
\hline & \multirow[t]{2}{*}{ Detail Window } & M Woodwork \\
\hline & & P Metalwork \\
\hline & Detail Ironmongery & M Woodwork \\
\hline \multirow{5}{*}{ Internal Doors and Windows } & \multirow[t]{2}{*}{ Detail Door } & M Woodwork \\
\hline & & P Metalwork \\
\hline & \multirow[t]{2}{*}{ Detail Window } & M Woodwork \\
\hline & & P Metalwork \\
\hline & Detail Ironmongery & M Woodwork \\
\hline \multirow[t]{2}{*}{ Internal Floor Finishes } & \multirow{2}{*}{ Detail Internal Floor Finishes } & S Floor, Wall and Ceiling Finishings \\
\hline & & U Painting and decorating \\
\hline \multirow[t]{2}{*}{ Internal Wall Finishes } & \multirow[t]{2}{*}{ Detail Wall Finishes } & S Floor, Wall and Ceiling Finishings \\
\hline & & U Painting and decorating \\
\hline \multirow[t]{2}{*}{ Internal Ceiling Finishes } & \multirow[t]{2}{*}{ Detail Internal Ceiling Finishes } & S Floor, Wall and Ceiling Finishings \\
\hline & & U Painting and decorating \\
\hline \multirow[t]{2}{*}{ Internal Floor Finishes } & \multirow[t]{2}{*}{ Detail Skirting Finishes } & S Floor, Wall and Ceiling Finishings \\
\hline & & U Painting and decorating \\
\hline \multirow[t]{4}{*}{ External Finishes } & \multirow[t]{2}{*}{ Detail Wall Finishes } & S Floor, Wall and Ceiling Finishings \\
\hline & & U Painting and decorating \\
\hline & \multirow[t]{2}{*}{ Detail Feature Wall } & S Floor, Wall and Ceiling Finishings \\
\hline & & U Painting and decorating \\
\hline Sanitary Fittings & Detail Sanitary Fitting & $\begin{array}{l}\text { Q Plumbing and Mechanical } \\
\text { Engineering Installations }\end{array}$ \\
\hline & Sanitary Fitting Schedule & $\begin{array}{l}\text { Q Plumbing and Mechanical } \\
\text { Engineering Installations }\end{array}$ \\
\hline $\begin{array}{l}\text { Cold Water and Sanitary } \\
\text { Plumbing }\end{array}$ & * Not under scope of work & $\begin{array}{l}\text { Q Plumbing and Mechanical } \\
\text { Engineering Installations }\end{array}$ \\
\hline Builders Work in Connection & Detail Ablution & F Concrete Work \\
\hline & & G Brickwork and Blockwork \\
\hline & & K Waterproofing and Asphalt work \\
\hline & & $\begin{array}{l}\text { Q Plumbing and Mechanical } \\
\text { Engineering Installations }\end{array}$ \\
\hline Flag Pole (Provisional Item) & Detail Flag Pole & *Others \\
\hline
\end{tabular}


Table 4. Synchronized bills of quantities of building works with architectural tender drawings based on the elements of building works for office building $\mathrm{A}$

\begin{tabular}{|l|l|}
\hline Bills of Quantities & \multicolumn{1}{|c|}{ Architectural Tender Drawings } \\
\hline $\begin{array}{l}* \text { To be measured under different } \\
\text { bill }\end{array}$ & Preliminaries Item \\
\hline $\begin{array}{l}\text { Apron Ramps and Perimeter } \\
\text { Drain }\end{array}$ & Detail Apron, Ramps, Steps And Perimeter Drain (Apron \& Ramp) \\
\cline { 2 - 2 } Staircase & Detail Apron, Ramps, Steps And Perimeter Drain (Drain) \\
\cline { 2 - 2 } & Detail Staircase (Concrete works) \\
\cline { 2 - 2 } & Detail Staircase (Railing) \\
\cline { 2 - 2 } & Detail Staircase (Finishes) \\
\hline \multirow{5}{*}{ Detail Apron, Ramps, Steps And } \\
\hline Roof & Perimeter Drain (Steps) \\
\hline External Wall & Setail Roof \\
\hline Internal Wall and Partition & Detail External \& Internal Wall \\
\cline { 2 - 2 } External Doors and Windows & Detail Louvres \\
\cline { 2 - 2 } & Detail External \& Internal Wall \\
\cline { 2 - 2 } & Detail Door \\
\cline { 2 - 2 } & Detail Window \\
\hline Internal Doors and Windows & Detail Doonongery \\
\cline { 2 - 2 } & Detail Window \\
\cline { 2 - 2 } & Detail Ironmongery \\
\hline Internal Floor Finishes & Detail Internal Floor Finishes \\
\cline { 2 - 2 } & Detail Skirting Finishes \\
\hline Internal Wall Finishes & Detail Wall Finishes \\
\hline Internal Ceiling Finishes & Detail Internal Ceiling Finishes \\
\hline External Finishes & Detail Feature Wall \\
\hline Sanitary Fittings & Detail Sanitary Fitting \\
\cline { 2 - 2 } & Sanitary Fitting Schedule \\
\hline Builders Work in Connection & Detail Ablution \\
\hline Flag Pole (Provisional Item) & Detail Flag Pole \\
\hline
\end{tabular}

Table 5. Synchronized architectural tender drawings with bills of quantities of building works based on the elements of building work for office building A

\begin{tabular}{|l|l|l|}
\hline Architectural Tender Drawings & Bills of Quantities & Clarification \\
\hline Preliminaries Item & *To be measured under different bill & $\begin{array}{l}\text { Drawings for preliminaries item } \\
\text { provide in architectural tender drawings } \\
\text { set. Information inclusive of hording } \\
\text { material, sign board, and temporary } \\
\text { office }\end{array}$ \\
\hline $\begin{array}{l}\text { Detail Apron, Ramps, Steps And } \\
\text { Perimeter Drain }\end{array}$ & Apron Ramps and Perimeter Drain & $\begin{array}{l}\text { The steps detail should be in Staircase } \\
\text { drawings. }\end{array}$ \\
\hline Detail Staircase & Staircase & $\begin{array}{l}\text { The staircase detail should indicate of } \\
\text { material used whether it is concrete } \\
\text { works, woodwork or metal work; } \\
\text { finishes; and railing. }\end{array}$ \\
\hline $\begin{array}{l}\text { Detail Apron, Ramps, Steps And } \\
\text { Perimeter Drain (Steps) }\end{array}$ & Staircase & $\begin{array}{l}\text { The detail should be separated and } \\
\text { titled under steps detail. }\end{array}$ \\
\hline Detail Roof & Roof & $\begin{array}{l}\text { The detail pertaining roof should } \\
\text { indicate the type of roof . For example } \\
\text { slate, tiled or concrete flat roof. }\end{array}$ \\
\hline Scupper Drain Detail (flat roof) & Roof (flat roof) & $\begin{array}{l}\text { Scupper Drain detail should be } \\
\text { inclusive in roof detail. }\end{array}$ \\
\hline Detail External \& Internal Wall & $\begin{array}{l}\text { External Wall } \\
\text { Internal Wall and Partition }\end{array}$ & $\begin{array}{l}\text { Indication of Internal wall and external } \\
\text { can be done by just indicating ust 'wall' } \\
\text { This is because identification can be } \\
\text { varies by different QS. }\end{array}$ \\
\hline Detail Louvres & $\begin{array}{l}\text { The louvres detail should be in External } \\
\text { and Internal wall }\end{array}$ \\
\hline Detail Door & External Wall & $\begin{array}{l}\text { The door, window, and } \\
\text { ironmongery is ideally separated } \\
\text { for easier quantification. }\end{array}$ \\
\hline Detail Window & External Doors and Windows & \\
\hline Detail Ironmongery & Internal Doors and Windows &
\end{tabular}


Table 5 (continued)

\begin{tabular}{|c|c|c|}
\hline Architectural Tender Drawings & Bills of Quantities & Clarification \\
\hline Detail Internal Floor Finishes & \multirow[t]{2}{*}{ Internal Floor Finishes } & \multirow[t]{2}{*}{ No modification } \\
\hline Detail Skirting Finishes & & \\
\hline Detail Wall Finishes & Internal Wall Finishes & No Modification \\
\hline Detail Internal Ceiling Finishes & Internal Ceiling Finishes & No Modification \\
\hline Detail Wall Finishes & \multirow[t]{2}{*}{ External Finishes } & \multirow[t]{2}{*}{ No Modification } \\
\hline Detail Feature Wall & & \\
\hline Detail Sanitary Fitting & \multirow[t]{2}{*}{ Sanitary Fittings } & \multirow[t]{2}{*}{ No Modification } \\
\hline Sanitary Fitting Schedule & & \\
\hline Detail Ablution & Builders Work in Connection & No Modification \\
\hline Detail Flag Pole & Flag Pole (Provisional Item) & No Modification \\
\hline
\end{tabular}

Table 6. Recommended model of Synchronized Architectural Tender Drawings and Bills of Quantities of Building Works Based on the Elements of Building Works

\begin{tabular}{|c|c|c|}
\hline Architectural Tender Drawings & Bills of Quantities & Clarification \\
\hline Preliminaries Item & *To be measured under different bill & $\begin{array}{l}\text { Information of hording material, sign } \\
\text { board, and temporary office }\end{array}$ \\
\hline $\begin{array}{l}\text { Detail Apron, Ramps, and Perimeter } \\
\text { Drain }\end{array}$ & Apron Ramps and Perimeter Drain & $\begin{array}{l}\text { Indicate the location in the proposed } \\
\text { building }\end{array}$ \\
\hline Detail Staircase & Staircase & $\begin{array}{l}\text { Indicate location of staircase and } \\
\text { steps, with specifying the material, } \\
\text { railing, finishes }\end{array}$ \\
\hline Detail Roof & Roof & $\begin{array}{l}\text { Indicate the type of roof, inclusive } \\
\text { Scupper drain information }\end{array}$ \\
\hline Detail External \& Internal Wall & $\begin{array}{l}\text { External Wall } \\
\text { Internal Wall and Partition }\end{array}$ & $\begin{array}{l}\text { Indication of type of wall, example } \\
\text { brickwork, and partition wall }\end{array}$ \\
\hline Detail Louvres & External Wall & Indicate the location and material \\
\hline Detail Door & \multirow{3}{*}{$\begin{array}{l}\text { External Doors and Windows } \\
\text { Internal Doors and Windows }\end{array}$} & \multirow{3}{*}{$\begin{array}{l}\text { The door, window, and } \\
\text { ironmongery is ideally separated } \\
\text { for easier quantification }\end{array}$} \\
\hline Detail Window & & \\
\hline Detail Ironmongery & & \\
\hline Detail Internal Floor Finishes & \multirow[t]{2}{*}{ Internal Floor Finishes } & \multirow[t]{2}{*}{ Indicate floor and skirting finishes } \\
\hline Detail Skirting Finishes & & \\
\hline Detail Wall Finishes & Internal Wall Finishes & Indicate wall finishes \\
\hline Detail Internal Ceiling Finishes & Internal Ceiling Finishes & Indicate internal ceiling finishes \\
\hline Detail External Ceiling Finishes & External Finishes & Indicate external ceiling finishes \\
\hline Detail Wall Finishes & \multirow[t]{2}{*}{ External Finishes } & \multirow[t]{2}{*}{ Indicate Wall Finishes } \\
\hline Detail Feature Wall Finishes & & \\
\hline Detail Sanitary Fitting & \multirow[t]{2}{*}{ Sanitary Fittings } & \multirow[t]{2}{*}{ Indicate sanitary fittings } \\
\hline Sanitary Fitting Schedule & & \\
\hline Detail Ablution & Builders Work in Connection & $\begin{array}{l}\text { Indicate detail that contain the } \\
\text { information of material used, sanitary } \\
\text { fitting, and finishes }\end{array}$ \\
\hline Detail Flag Pole & Flag Pole (Provisional Item) & $\begin{array}{l}\text { Indicate detail that contains } \\
\text { information of material used and } \\
\text { finishes. }\end{array}$ \\
\hline
\end{tabular}

\section{Conclusion and recommendation}

The purpose of the study is to have documents mutually explanatory of each other in the case of any discrepancy. Love et al. [16] identified that the use of 'time boxing' practices to meet schedule demands may contribute to audits, reviews and verifications being omitted, thus allowing design errors to materialize during construction. Therefore, the proactive measure that found under this study is to simplify coordination even though consultants had limited time to revise documents.

The study found out that the discrepancies of documents can be minimized by synchronizing drawings and documents. The study by Jha and Iyer [18] analysed that influencing coordination activities that related to this study, are that preparation of a project quality plan in line with contract specifications and arrangement of required inputs like drawings, specifications and technical details. Twort and Rees [19] suggested that specification for workmanship and materials of civil engineering works is by listing trades in the ICE Standard method of billing quantities (CESMM) in order which construction normally proceeds, to help drafting and make sure matters are not missed. This similar method has drawn the comparison process between building elements of Standard Method of Measurement, building works elements in the bills of quantities and architectural drawings in table 5. The required architectural detailing is identified based on building elements that already stated 
in the Standard Method of Measurement (SMM). Finally, as shown in table 6 , the recommended method to produce 2-D architectural drawings is based on elements of building works that the bills of quantities in used. However, the addition of other detail will be based on design requirements. For example the usage the element demolition, architectural drawings will be provided accordingly.

Love et al. [16] suggested that error prevention should be viewed as a continuous process, rather than a product of certain activities or behaviors, as it involves an exploration of people, organisations and project systems. Thus, the recommended model can be taken into further account by diversifying the unit analysis into implementation of multiple projects for observation contrasting patterns in data, considering the design requirement and complexity.

\section{References}

1. P. A. Malaysia, Agreements And Conditions Of PAM Contract 2006 (Without Quantities) (2006)

2. Public Works Department, Standard Form of Contract to be Used Where Bills of Quantities Form Part of the Ccntract PWD Form 203A (Rev 1/2010) (2010)

3. P. I. Tan, K. S. Low, J. Sum, and S. T. Chee, Handbook for PAM Contract 2006. Kuala Lumpur: PAM Publication (2010)

4. S. Z. H. S. Jamaludin, M. F. Mohammad, and K. Ahmad, "Enhancing the Quality of Construction Environment by Minimizing the Cost Variance," Procedia - Soc. Behav. Sci., vol. 153, pp. 70-78 (2014)

5. Y. Frimpong, J. Oluwoye, and L. Crawford, "Causes of delay and cost overruns in construction of groundwater projects in a developing countries; Ghana as a case study," Int. J. Proj. Manag., vol. 21, no. 5, pp. 321-326 (2003)

6. M. Sambasivan and Y. W. Soon, "Causes and effects of delays in Malaysian construction industry," Int. J. Proj. Manag., vol. 25, no. 5, pp. 517-526 (2007)

7. N. Mansfield, O. Ugwu, and T. Doran, "Causes of delay and cost overruns in Nigerian construction projects," Int. J. Proj. Manag., vol. 12, no. 4, pp. 254260 (1994)

8. a. M. Odeh and H. T. Battaineh, "Causes of construction delay: Traditional contracts," Int. J. Proj. Manag., vol. 20, no. June 2000, pp. 67-73 (2001)

9. Y.-M. Cheng, "An exploration into cost-influencing factors on construction projects," Int. J. Proj. Manag., vol. 32, no. 5, pp. 850-860 (2014)

10. H. J. Rosen and J. Regener, Construction Specifications Writing: Principles and Procedures (Fifth Edition). Hoboken, New Jersey: Wiley \& Sons. (2005)

11.D. Arditi and H. M. Gunaydin, "Total quality management in the construction process," Int. J. Proj. Manag., vol. 15, no. 4, pp. 235-243 (1997)

12. J. E. Connell and T. M. Flegal, Chapter 28 Contract
Documents, Third Edit., no. 1. ButterworthHeinemann (2011)

13. J. A. Sani and N. Othman, "Quality Standard and Specification for Soft-scape Construction in Malaysia," Procedia - Soc. Behav. Sci., vol. 35, no. December 2011, pp. 260-266 (2012)

14. S. K. S. Harbans and K. S. Kandan, "Variation Claims The Pitfalls And Pratfalls *," Bul. Ingenieur,The Board Eng. Malaysia, vol. 24, pp. 36-42 (2005)

15. M. Jaafar, L. Y. Mui, and I. Yahaya, Elementary Estimating For Building Works. Penerbit Universiti Sains Malaysia (2013)

16. P. E. D. Love, R. Lopez, D. J. Edwards, and Y. M. Goh, "Error begat error: Design error analysis and prevention in social infrastructure projects," Accid. Anal. Prev., vol. 48, pp. 100-110 (2012)

17. A. De Massis and J. Kotlar, "The case study method in family business research: Guidelines for qualitative scholarship," J. Fam. Bus. Strateg., vol. 5, no. 1, pp. 15-29 (2014)

18. K. N. Jha and K. C. Iyer, "Critical determinants of project coordination," Int. J. Proj. Manag., vol. 24, no. 4, pp. 314-322 (2006)

19. A. Twort and G. Rees, "5 Preparing contract documents," in Civil Engineering Project Management (Fourth Edition), 4th Editio., London: Elsevier Butterworth-Heinemann (2004) 